\title{
On Politeness in Translation
}

\author{
Tatyana P. Tretyakova* \\ St. Petersburg State University \\ 11 University Embankment, St. Petersburg, 199034, Russia
}

Received 15.01.2016, received in revised form 07.02.2016, accepted 24.02.2016

The category of Politeness is nowadays a concept which is heavily studied in cultural studies and pragma- linguistics. The aim of this article is to show some major problems of linguistic politeness in connection with the translation studies. There are the following areas under discussion: the concept of negative and positive politeness, speech etiquette, cross and intercultural differences in politeness. As a result it is argued that context pragmatics and translation maneuvering with integrated areas of text potential, audience demand and presentational devices may provide function equivalence in representation of politeness.

Keywords: linguistic politeness, verbal etiquette, translation studies, inter- cultural communication, function equivalence, context pragmatics, translation maneuvering.

DOI: 10.17516/1997-1370-2016-9-3-653-661.

Research area: philology.

\section{Introduction}

Politeness as a universal term is interpreted as a desire to be 'nice' to other people in order to create positive communicative relations. This understanding of politeness is close to moral and ethical norms accepted in the society and it is connected with customs of social and individual behavior in different types of environment. Politeness has become an attractive field of research by scholars of diverse academic fields: social psychology, sociolinguistics, linguistic pragmatics, social anthropology, cross-cultural studies and translation studies.

In the 21-st century (im) polite forms are reflecting certain powerful relations conducting individual and group discourses. There has been devised a whole repertoire of cooperative polite behavioral rules for effective socializing in many kinds of professional discourse types. These rules are represented by the choice of verbal and nonverbal codes used in the situations of addressing, meetings, greetings, expressing condolences, apologizing, requests and invitations, agreements and disagreements, approvals and disapprovals, and many other functional spheres of socializing. New theoretical approaches are being suggested and new empirical data represented in recent western and non-western studies and including linguistic politeness. Special emphasis is laid upon effective cross cultural institutionalized and non-institutionalized communication skills. In 2015 there was marked the tenth anniversary of the Journal of Politeness Research published by Walter de Guyter (Journal of Politeness research

(C) Siberian Federal University. All rights reserved

* Corresponding author E-mail address: ttretyakova@eu.spb.ru, tretyakova.tp.50@gmail.com 
2015). All this shows the rising interest in the research of this concept.

In everyday life in face-to-face communication politeness is manifested through verbal and non-verbal etiquette codes. This manifestation provides the establishment of positive relationship between communicants demonstrating respect, compassion, desire to continue contacts etc. There are two basic levels of politeness studies: one level corresponds to various ways in which polite behavior is perceived by people belonging to different socio-cultural groups, and the second level concerns a theory of social behavior and language usage (Politeness in Language 2005).

Modern media and globalization at large put politeness concept as an influential factor for effective socializing. Moreover, nowadays even computer mediated communication involving human-to-human interaction as well as interaction facilitated by computer applications (both synchronous and asynchronous) has its own politeness recommendations which are under control of mediators. In computer-mediated environment special forms of netiquette (netetiquette) appeared to oppose "impolite" strategies of flamings, trollings, hotlinking, spams etc.

Thus, (im-)politeness and the observation of the rules of politeness become quite powerful in terms of following universally accepted etiquette codes. Positive and attractive selfpresentation, correct word choices reflect both individual and group politeness. Then we speak of political etiquette, diplomatic etiquette or everyday etiquette depending on the situational context. From this we can conclude that existing individual and group politeness is connected with the development of polite codes in different social and cultural contexts.

The aim of this article is to give a general outline of politeness concept in reference to translation studies. In order to do this we cover three major mappings of possible research activity incorporating translation studies in the field of politeness equivalence. First, we shall observe some aspects of modern interpretation of linguistic politeness concept as a social and cultural matter, and then we shall cover some samples of interpretation of verbal politeness in translations with the help of translation maneuvering concept implying integrated approach to translation analysis.

\section{Linguistic Politeness and techniques of analysis}

1. The present day theory of Linguistic Politeness is a universally accepted theory which was developed after the studies of Geoffrey N. Leech (1983) and Penelope Brown and Stephen C. Levinson (1987). Their theory became most influential in linguistics despite existing criticism (Goldsmith 2007). Brown and Levinson argued that positive and negative face exist universally in all types of human culture and politeness as a universal phenomenon is a means to mitigate face threats and to maintain face in everyday interactions.

Negative politeness is concerned with the addressee's wish to maintain freedom of action and to remain free from imposition while positive politeness is concerned with the addressee's wish to be appreciated and liked by others. Taking into account positive and negative polite cultures it can be concluded that members of negative politeness cultures are more sensitive to negative face while members of positive politeness cultures are more attentive towards positive face needs. Impoliteness, then, refers to behaviors that attack positive face (e.g. when you criticize someone) or negative face (e.g. when you make demands on someone). These attacks are called 'face- threatening acts' (FTAs). In order to help the person maintain negative face you show your respect by using requests and not commands, i.e. 
by saying Would you mind opening the window? instead of Open the window! Maintaining positive face is done with the help of using the repertoire of polite formulae (clichés, etiquette phrases) Please or Thank you, Excuse me etc.

People with an Anglo-Saxon cultural background, might be more reluctant to allow threat to their negative face, more likely to apologize indirectly or avoid the confrontation than members of positive politeness cultures. At the same time, they might apologize more readily in situations involving damage to addressee's negative face; situations which may not require an apology in positive politeness cultures. This fact is reflected in the overuse of the expressions Sorry; Sorry, my fault, Pardon in the situations which do not necessarily require apologizing. In this case we can speak of linguistic process of stereotyping when polite etiquette expressions function in some other communicative field. Functional shifts can be quite unpredictable, as for instance the use of Russian etiquette units of Здравствуйте and Пожалуйста which coined into the phrase 3драссте-Пожалуйста used as a disapproval surprise utterance in face-to-face communication thus leaving the domain of polite etiquette field.

The two types of politeness under discussion are subdivided into a large number of different strategies depending on FTA. The choice of strategies depends on speaker's ability to correctly assess such factors of communication as Power, Distance and Imposition. The labelling of the types of culture as far as cultural differences are concerned is connected with the awareness of these differences as stereotypes. (Tretyakova, 2015b)

The research into Politeness from this standpoint showed that members of negative politeness cultures are particularly sensitive to negative face and members of positive politeness cultures are more attentive towards positive face needs Criticism of this approach showed that not all concepts are universal. It was found out that FTA, for instance, is irrelevant in giving and receiving advice as there was no face sensitivity between interlocutors. (Goldsmith, MacGeorge (2000); Goldsmith, 2007) J. House in evaluating Brown and Levinson theory wrote: "However, Brown and Levinson do not provide any indication as to how speakers are to assess the values of these dimensions in any individual act. Further, the notion of face seems to be derived from an Anglophone individualistic notion of face closely linked to status and implying competition and prestige.”(House 1998:57)

From this we can conclude that politeness is associated with principles of social organization where appropriate verbal behavior is taken as a reflection of influential (universally accepted) pattern of social interaction. Functional fields of polite interaction are defined as markers of correct personal disposition. Moreover, here we may argue that politeness belongs to the sphere of 'habitus' (Bourdieu) as a socialized form that guides behavior or the way when repeated disposition of establishing positive socializing between addressant and addressee determines personal, cultural, institutional patterns of avoiding contradictions and conflicts. All this is connected with the nature and the distribution of power. Richard Watts in his research showed that the concept of politeness in 18th century Britain considers it as a means to gain "access to high social status from which power could be exercised" (Watts 2003: 40).

Different societies and social groups provide variables in politeness norms constituting all sorts of stereotypes. Besides, the stereotypes change in time. For example, Eva Ogiermann connected the change in polite communication in Polish and Russian with the change of political situation in these countries after the fall of 'Iron Curtain'. (Ogiermann 2009:41-42) 
A.Jucker, covering the development of verbal politeness concept in English with special reference to courtesy, chose one of Brown and Levinson's negative strategy as 'discernment politeness', 'deference politeness' and 'non-imposition' politeness that give the addressee a choice of reaction. It is close to Watts's concept of firstorder politeness which is reflected in the various language terms as 'considerate', 'thoughtful', 'well-mannered' as synonyms of the English 'polite' and 'courteous'. (Watts:2003: 35; Jucker, 2012)

Using Helsinki Corpus for the research allowed scholars studying historical pragmatics to reveal areas of higher or lower density of politeness related vocabulary at particular points in the history of the English language and in specific prototypical text categories. The Study also showed that courtesy and politeness are such complex and multi-faceted concepts that linguistic analysis can reveal only a partial picture. (Jucke r,Taavitsainen\&Schneider2012) The development of the politeness studies incorporating cultural contexts and historical pragmatics allowed to devise new linguistic interpretive techniques for describing pragmatic meaning of polite utterances. (Jucker, 2012; Tretyakova, 2012; Tretyakova, Tsvinaria, 2013)

The knowledge concerning Politeness concept becomes indispensable for the translator because there are a lot of inferential and covert meanings that exist in the cultural contexts of the author (addressant), translator and the reader (addressee). The translator works as a cultural mediator who does not know in many cases his/ her target-audience/readers preferences.

2. One more field of politeness research concerns the study of polite etiquette forms of expression. In linguistics etiquette is understood as a system of rules and rituals that regulates social and professional behavior. These social rules are quite coercive; they reflect customary behavioral laws of socializing the violation of which may lead to quite serious complications as a breach may be considered a serous insult.

The term 'etiquette' came from French, derivative of the word étiqu(i) (-to attach, stick). In French it meant a memorandum, a reminder. First it was used to denote small cards (written or printed) with instructions how to behave properly at court. At present the term speech etiquette is looked upon as a language universalia, a special cultural verbal code reflecting a bunch of rules prescribed by cultural and language tradition and social memory. The types of etiquette are numerous - military, business, diplomatic, everyday etc. On the one hand, etiquette is a system of signs used in particular situations, and on the other, this phenomenon is a complex of regulatory rules.

The universal etiquette schema is connected with the knowledge of polite establishing and terminating the contact. The classification of the etiquette repertoire is connected with functional fields of language use and language register. The sphere of cultural differences in expression of politeness covers address forms and ways of greetings, etiquette formulas, euphemisms, turntaking and turn-yielding etc. (Tretyakova, 2014a; Tretyakova, 2014b)

Changes in Politeness behavior reflect social attitudetomanyetiquetteforms. Forexample, many address forms that existed in the 19-th century in Russia aren't used any more: Ваша светлость, Ваша милость, Ваше сиятельство, Ваше благородие, сударь (сударыня), милостивый государь (государыня). In English at the end of the $20^{\text {th }}$ century appeared the address form to women Ms.

The flexibility of etiquette systems in languages should always be the concern of translation although it is difficult to do. For example, formal English greeting How do you do? in the informal situation bears an ironic meaning which sometimes is reflected in a writing as 
How-d'ye-do? and a contracted form of Howdy is now an equivalent of Hello! The observation of the register and conversational manner/tone are important factors for correct interpretation of politeness in interpersonal relations.

Etiquette verbal forms provide a system of "filters" used in the dialogue for which may be different in different cultures. They work as formulas encoding social memory, situational context and pragmatic meaning.

3. Dimensions of cross-cultural and intercultural differences mostly lie in social norms reflecting the differences In Politeness standard norms. The very interpretation of politeness concept is different in different cultures. In English the word polite was conceptualized for the reference of polite behavior in the 18-th century. The meaning of the English word is linked with manners accepted in court (courteous) whereas the Russian adjective vežlivyj is derived from the verb vedat' (to know) and hence a polite Russian is knowledgeable and the lack of knowledge makes him/her a neveža, an ignorant person (Ogiermann 2009: 40-42). Thus, from the very start the very act of polite contact bore differences in different cultures.

At present day Russian television program 'Rules of Life' televised by Kultura Channel allots time for the discussion of cross-cultural differences in communication. For example, such characteristics of Russian verbal communication tradition as openness, directness, explicitness is compared to self- irony, implicitness, indirectness in English verbal culture. Interlocutors may use not only words but a tone of voice that comes across as polite or not so polite.

Politeness and impoliteness may manifest themselves on very different levels. They may accompany their words with facial expressions or gestures that render what they say as more or less polite. Moreover, politeness and impoliteness are situational and individualistic, and to some extent they may even be unintentional. All this factors are of great interest to cultural and linguistic studies. (Larina, 2009; Locher, 2015)

Social factors of individual and group systems are characterized by a 'T/V subsystem' ,e.g. 'ты/Bы' in Russian and 'du'/ 'Sie' in German , 'tu/Vous' in French. V- forms of address are used as signs of polite respect or formal register of interaction, whereas $\mathrm{T}$ - forms show less formal communication or less formal polite forms of address. In English there is no formal language difference in the use of the pronoun you which can be polite (Could you/would you...; do you mind...? Will you...?) or quite neutral. A Wierzbicka, who started the study of cross-cultural pragmatics, considers English you showing more cordiality, courtesy, intimacy and friendliness etc. than Slavic «ты» (Wierzbicka 1991:56-57). In Russian there is an expression « Перейти на «ты»» which means 'to transfer to more close and friendly relationship in communication'. If we try to make literal translation of the phrase the meaning would be completely lost.

The comparison of English phrase Please and Russian Пожалуйста as communicative etiquette codes for functional polite fields we will find a lot of differences. For example, the standard situation is the case of saying thank you. In Russian it is codified in the utterances of 'Спасибо'-'Пожалуйста'. In English this etiquette situational phrase refers to here you are/ you're welcome. Russian speakers do not always associate the last phrase with пожалуйста. Very often the phrase you're welcome is taken for не за чmo! Used in everyday speech, the Russian phrase implies that the person who made some beneficiary for the speaker doesn't want any additional gratitude. The direct meaning of the cliché is There is nothing to thank me for. One more example with Russian Пожалуйста appears as a nonchalant permission or consent to do something when asked for one. Sometimes it 
shows a sort of annoyance: - $Я$ все же хотел уйти сейчас /- Пожалуйста! (I'd still like to leave now - Sure/Go ahead. Equivalence of function is reflected in different etiquette phrases which can be identified only with the help of contrastive analysis and context pragmatics. (Tretyakova, 2014a)

Context pragmatics is an approach which helps identifying functional semantics of utterances through the integration of three specific areas. One of these areas is concerns the <egodu-hic-nunc $>$ communicative situation. It means that the matrix for the analysis is connected with $<$ face-to-face $>$ communication including such parameters as <addresant-addressee $>$ relations, the second area is connected with the knowledge of situational conventions, i.e. standard norms or deviation of from accepted conventions and the third aspect concerns the rhetorical impact of the utterance. The integration of these three aspects allows interpreting politeness equivalence in terms of functional semantics.

\section{Politeness and Translation: \\ integrated approach of translation maneuvering}

Translation as a cross linguistic as well as sociocultural practice inevitably fails to conceive absolute equivalence in SL and TL because of cross-cultural and intercultural differences of politeness standards and differences in linguacultural aspects of manifestation of the rules of Politeness.

In his article Translation as an intercultural communication David Katan covered three interrelated problem areas covering the relevance of cultural differences in translation. The first area concerns the definition of culture which has apart from 'humanistic' ideal of what was civilized in a developed society and the anthropological understanding as the way of life of people and its social and ideological aspect. (Katan, 2009)
The second problem area covered a historical division of two approaches to translation as an encoding and decoding linguistic activity transferring meaning from SL to the TL or as a context biased phenomenon when "meaning is not 'carried' by the language but is negotiated between readers from within their own contexts of culture". In the latter case "readership is bound to receive the text according to their own expectations and translation becomes a kind of mediation or manipulation. (op.cit.: 74-75)

The third area concerns the so called 'culture filter' or 'cultural filter' which is responsible for orienting and modelling our own perception, interpretation and evaluation, i.e. a means of capturing with cognitive and sociocultural differences which translators apply to the translation (op.cit. 75-76). This third area, is relevant to context -pragmatics discussed earlier. The understanding of the role of culture in translation is very close to the concept of functional translation maneuvering model introduced for the analysis of stereotype phrases. (Tretyakova 2015a)

According to this concept there are three aspects that are integrated into the translation analysis - topical potential, audience demand and presentation devices. Of course, they do not exist separately and there is a constant interaction between them. First, the topical potential brings a whole variety of subtypes which can be defined in terms of the conversational and politeness maxims and context commitment etc. For example, in case of politeness analysis in everyday discourse these may be setting for greeting, saying good-bye, expressing condolences, toasting etc. Linguistic insights consider the differences between the SL$\mathrm{TL}$ in the situational analysis. Topical potential helps in orientation in different 'polite worlds' The violation of the topical potential might bring disorientation and sometime cultural shock or misunderstanding. 
Theo Hermans when discussing the problem of translation in reference to ethics and politics gives an example of translating several 'touchy' topics: "kaffir" the word that was outlawed in in post-apartheid South Africa or The Satanic Verses by Salman Rhushdie or feminist literature. The issues of stereotypes and otherness raise questions that do not have easy answers especially in the current global scene (Hermans, 2009). The issues of otherness and cross-cultural differences in representation of topics put forward the issue of politeness in a different flavor to the concept of Politeness in terms of transfer from English tradition and incorporating 'the otherness'.

Second, audience demand, when speaking of translations having in the focus on the acceptability of translation by reading public or film spectators. Sometimes necessary adjustments are done for better understanding or adaptation of the text according to some ethical, ideological matters (Hermans, 2009). This type is close the concept of 'culture filter' mentioned above. In this case the complications in perception of the translation may appear because the audience may be a heterogeneous group and a target reader or spectator has his or her own view of the world. The research of Eva Ogiermann devoted to the act of apologizing starts with Geoffrey Leech quotation:"I have been seriously told that 'Poles/ Russians/etc. are never polite”" (Leech 1983:84) which, of course, is not true. Studying the act of apologizing and variables in politeness expression in Polish and Russian, the author "attempts to integrate cultural values underlying the perception of what constitutes polite behavior into their potentially universal framework" (Ogiermann, 2008:1).

The audience demand is important in everyday vis-a vis situations. David Katan brings forth the example of translation the order in a restaurant made by a well-mannered Spanish woman: Un ristresso, doppio, caldissimo,- disse al camerier. The foreignized translation into English would be: 'A concentrated, double, very hot', she said to the barman "will leave the Anglophone reader bewildered, as none of the words directly cue 'coffee' (Katan 2009:84). The topical potential is distorted there is no mentioning of coffee. Moreover, the English translation and ' cultural' filters violate politeness norms of the audience demand. The speaker is likely to be regarded as a very rude person. This example shows close connection between topical potential and audience demand. The politeness was added in translation: She asked the barman for an espresso, 'thick, double and really hot.' With this audience demand the analysis of presentational devices comes up.

Third, there is the use of presentational devices which involves a choice of the best ways of reconstruction the pragmatic effect. The choice of best possible devices here concerns the case of what Juliane House called overt and covert translations. Overt translation covers the case when the original is "source-culture linked and has independent status in the source-language community" (House 1998:65), it is a kind of 'language mention', when the function equivalence is achieved in what Juliane House calls Language, Genre and Register. In the case of covert translation the translator re-creates an equivalent speech event and "to reproduce or represent in translation text the function the original has in its original linguistic-cultural framework, i.e. /real' function equivalence is aimed at"(op.cit.:65-66). Here presentation devices are chosen with the reference to culture filters discussed above. For example the translation of stereotypes, including etiquette ones. (Tretyakova, 2015a)

The differences of the devices in this case are connected with the effective tools of language choice and presentational variations. In this case tropes, figures of speech, speech registers and all language phenomena used for creating cohesion 
in the text and highlighting special facets in the text. The existence of universal and particular audience implies the use of the linguistic devices that the audience might understand and there would be the equivalence of functions.

\section{Conclusion}

Integrated semantics of Politeness lies in the fields of cultural studies, context analysis and the schemata of stereotyping. Translation of politeness requires treating this phenomenon through integrated interpretation. The translator becomes a mediator who should be aware of different 'polite mappings'. The general model of translation process includes such areas as context pragmatics and translation maneuvering with the possibility of functional manipulation.

\section{References}

Brown, P., Levinson, S.C. (1987). Politeness: Some universals in language usage. Cambridge University Press, $358 \mathrm{p}$.

Goldsmith, D.J., MacGeorge, E. L. (2000) The impact of politeness and relationship on perceived quality of advice about a problem. In Human Communication Research, 26, 2, 234-263.

Goldsmith, D. J. (2007) Brown and Levinson's politeness theory. In Explaining communication: Contemporary theories and exemplars (Eds. B. Whaley \& W. Samter.), 219-236.

Hermans, Th. (2009). Translation, ethics and politics. In The Routledge companion to Translation Studies. Revised edition ed. by Jeremy Munday, 93-105.

House, J..(1998). Politeness and Translation. In The Pragmatics of Translation. Ed. by Leo Hickey. Topics in Translation: 12, 54-71.

Journal of Politeness Research (2015), 11,2 , 165- 364. Ed. by Grainger, Karen., available at: http://www.degruyter.com/view/j/jplr/

Jucker, A. H. (2012). Changes in politeness cultures. In Terttu Nevalainen and Elizabeth Traugott (eds.) The Oxford Handbook of the History of English, New York, 422-433.

Jucker, A. H., Taavitsainen I.\& Schneider G. (2012). Semantic corpus trawling: Expressions of "courtesy" and "politeness" in the Helsinki Corpus, In Studies in Variation, Contacts and Change in English 11: Developing Corpus Methodology for Historical Pragmatics. Available at: http://www. helsinki.fi/varieng/journal/volumes/11/jucker_taavitsainen_schneider/

Katan, D. (2009). Translation and intercultural communication. In The Routledge companion to Translation Studies. Revised edition ed. by Jeremy Munday, 74-92.

Larina,T.V. (2009). The category of politeness and styles of communication: comparison of English and Russian linguacultural traditions [Kategoriya vezhlivosty $i$ sopostavleniye anglyiskih I russkih lingviokulturnyh traditsyi]. Moscow, $512 \mathrm{p}$.

Leech, G. (1983). Principles of pragmatics. London: Longman, $250 \mathrm{p}$.

Locher, M A. (2015). Interpersonal Pragmatics and its link to (im)politeness research, In Journal of Pragmatics, 86, 5-10. Interdisciplinary perspectives on pragmatics: A Festschrift for Jonathan Culpeper

Ogiermann E. (2009). On Apologising in Negative and Positive Politeness Cultures. Pragmatics \& Beyond New Series.191. John Benjamin, 296 p.

Politeness in Language: Studies in Its History, Theory and Practice (2005). Editors Richard J. Watts, Sachiko Ide, Konrad Ehlich. Walter de Gruyter, 404 p. 
Tretyakova, T. P. (2012) Razvitiye rechevogo etiketa $v$ angliiskom yazyke [The development of speech etiquette in English], In Ocherki po istoricheskoy pragmatike germanskich yazykov [ Sketches on historical pragmatics in Germanic Languages]. Galina A. Baeva (ed). St. Petersburg, 104-145.

Tretyakova, T. , Tsvinaria M.(2013). Context pragmatics of samples of social discourse in Beowulf . In Ex Philologia Lux: Essays in Honour of Leena Kahlas-Tarkka (Mémoires de la Société Néophilologique de Helsinki XC), ed. by Jukka Tyrkkö, Olga Timofeeva \& Maria Salenius. Helsinki, Société Néophilologique, 241-260.

Tretyakova, T. P. (2014 a). On translating verbal etiquette phrases, In Journal of Siberian Federal University. Humanities \& Social Sciences 2 (7), 334-340.

Tretyakova, T. P. (2014b) Kodifikatsiya angliyskogo rechevogo etiketa:teoreticheskiye I istoricheskiye aspekty [Codification of English speech etiquette: theoretical and historical aspects], In Yazyk kak kulturny kod natsii [ Lanaguage as a cultural code of the nation]. St. Petersburg, 207-227.

Tretyakova, T. P. (2015a). Translation maneuvering and speech stereotypes in Harold Pinter's plays. In Journal of Siberian Federal University. Humanities \& Social Sciences, 2 (8), 300-307.

Tretyakova T. P. (2015b). The Matrix for Presenting the Meanings of Speech Clichés. In Life Beyond Tourism. Ed. by Olga M. Karpova and Faina I. Kartashkova, Newcastle upon Tyne: Cambridge Scholars Publishing, 155-164.

Watts, R. J. (2003). Politeness. Cambridge University Press, 304 p.

Wierzbicka, A.(1991). Cross-cultural Pragmatics. The Semantics of Human Interaction. Trends in Linguistics; Studies and Monographs. Berlin, Mouton de Guyter, 504p

\section{О вежливости в переводе}

Т.П. Третьякова

Санкт-Петербургский государственный университет Россия, 199034, Санкт-Петербург, Университетская наб., 11

Категория Вежливости в настоящее время активно изучается и культурологии и в прагма-лингвистике. Цель настоящей статьи - рассмотреть те основные проблемы лингвистической категории Вежливости, которые имеют отношение к переводу. В статье затрагиваются следующие проблемы: концепция положительной и отрицательной вежливости, речевой этикет, кросс- и интеркультурные различия в интерпретации вежливости в ИЯ и ПЯ. В результате делается вывод о необходимости привлечения методов контекстной прагматики и концепции переводческого маневрирования для достижения функциональной эквивалентности в представлении вежливости.

Ключевые слова: лингвистическая вежливость, положительная и отрицательная вежливость, речевой этикет, межкультурная коммуникация, функциональная эквивалентность, теория перевода, контекстная прагматика, переводческое маневрирование.

Научная специальность: 10.00.00 - филологические науки. 